Matteo Rescigno, Full Professor of "Diritto Commerciale" (Corporate Law) Università degli Studi di Milano, Italy

Lucia Folladori, Post-doctoral Research Assistant of "Diritto Commerciale"

(Corporate Law)

Università degli Studi di Milano, Italy

\title{
SUSTAINABLE BUSINESS: THE BENEFIT COMPANY MODEL ${ }^{1}$
}

\section{ILGTSPĒJĪGS BIZNESS: SABIEDRISKĀ LABUMA UZN,ĒMUMA MODELIS}

\begin{abstract}
Kopsavilkums
Uz pel̦nu orientēta uzṇēmējdarbība daudzējādā ziṇā aptver visu sabiedrību īpaši tādās jomās kā darbaspēks, veselība, vide un cilvēktiesības. Šis secinājums zinātnieku vidū raisījis būtiskas diskusijas par korporatīvo sociālo atbildību (KSA), meklējot atbildi uz šãdiem jautājumiem:

- Vai uzñēmuma vadītājiem, darbojoties biznesā, būtu jāpien,em lēmumi, n̦emot vērā ne vien akcionāru privātās intereses, bet arī t. s. ieinteresēto pušu (darba ñēmēju, piegādātāju, patērētāju un plašākas uzṇēmuma darbības ietekmētās sabiedrības daļas) intereses?

- Vai ieinteresētās puses būtu jāiesaista izvēles izdarišanā / lēmuma pieñemšanā pat lielākā mērā, nekā to prasa attiecīgās nozares likumdošana un noteikumi?

Raksta mērḳis ir rast atbildes uz šiem jautājumiem, analizējot atsevišķ kus korporatīvo tiesību noteikumus kā instrumentus ilgtspējīga uzṇēmējdarbības model̦a veicināšanai, kā tas noteikts Itālijā ar likumu Nr. 208/2015 par tā dēvēto "sabiedriskā labuma uzṇēmumu". Šàda īpaša uzn̦ēmuma forma radīta un attīstijjusies 34 ASV pavalstīs. Tā pieprasa uzṇēmumu direktoriem ne vien tiekties uz pel̦nas gūšanu kā galveno mērḳi, bet arī nodrošināt uzñēmuma darbību sociālo un vides ilgtspējỉbu.

Analizējot īpašos pārvaldības un tirgus informācijas noteikumus, kas paredzēti šādam uzṇēmuma veidam, rakstā vispirms norādīts, ka sabiedriskā labuma uzṇēmuma direktoru īstenotie daudzveidīgie mērki nevis palielina rīcības brīvību, pienemot vadības lēmumus, bet drīzāk to ierobežo, jo peḷnas gūšanas vārdā nedrīkst ignorēt pienākumu darboties sabiedriskam labumam, kas īpaši noteikts statūtos un atspoguḷo šĩ veida uzņēmējdarbības mērḳi.

Izmantojot tādus juridiskos veidojumus kā sabiedriskā labuma uzṇēmums, tiesiskajai sistēmai tiek uzticēta sociālās tirgus ekonomikas veidošana, kura pasludināta par Eiropas uzṇēmējdarbības likumdošanas mērḳi.
\end{abstract}

Atslēgvārdi: uzṇēmums, peḷna, ilgtspēja, korporatīvā sociālā atbildība

1 The paper is a result of discussion among the authors; although Matteo Rescigno is the author of paragraphs 5, 6, 7; Lucia Folladori is the author of paragraphs 2, 3, 4. Premise ( $\$ 1$ ) and conclusion ( $\$ 8)$ were written jointly. 


\section{Summary}

Profit-oriented business encompasses the whole society in many ways, incorporating several areas of influence: labour, health, environment, human rights.

Such an awareness has led to an important debate on Corporate Social Responsibility (CSR) among scholars wondering about the following questions:

- should the choices of executives in exercising their business activity take into account both the private interest of the shareholders and that of the so-called stakeholders (workers, suppliers, consumers and broadly the community affected by the company's business)?

- should stakeholders be involved in making choices, even beyond compliance with the rules governing the relevant sectors?

The paper aims to answer these questions, analysing some corporate law rules as tools to promote a sustainable business model, as the one set forth in Italy with the Law no. $208 / 2015$ on the so-called 'benefit company'.

Such particular corporate form - born and developed in the thirty-four states of the USA - requires of corporate directors to pursue not only the profit-making purpose, but also social and environmental sustainability of company's business.

Analysing the specific rules on management and market information provided for such form of corporation, the paper states first that the variety of purposes likely to be pursued by the directors in a benefit company does not increase their discretionary level in taking management decisions but rather limits it since the pursuit of common benefit - specifically set out in the bylaws and featuring the business purpose - cannot be disregarded to protect profit.

Through legal arrangements such as the benefit company the legal system is entrusted with the construction of a social market economy supposed to be the aim of the European company law.

Keywords: enterprise, profit, sustainability, Corporate Social Responsibility

\section{Introduction}

The social relevance of the business activity exercise has long been a matter of interest both to scholars and the law. The finding of the global rise of the market economy leads, in the legal systems of the advanced economies, to the questioning of the fact that the profit-oriented enterprise plays a role that, in many respects, affects the whole totality in general and as a community of players who, more closely, are directly influenced by it (labour, health, environment, human rights).

Commercial law can play an important role in shaping business models that include (also) the pursuit of socially useful purposes (both in the context of non-profit organizations and in the context of commercial profit-making undertakings).

Besides the public enterprise, the form of the cooperative, with the social cooperative as its daughter (established for management of social, health and educational services or to facilitate the entry of disadvantaged persons into the labour market), there are some 'new' models of business operation, recently an object of interventions by the Italian system reform, attesting to the ever more diffused development of the business activity hybridization dynamics, and using the scheme and the corporate to pursue ideal ends. 


\section{The so-called 'third sector'}

For a long time, in Italy (as in many other countries), the pursuit of altruistic aims has been a specific objective as predominantly the task of public enterprises. Moreover, the growing difficulty, on the part of the state, in efficient response to ensuring these 'social rights', has constituted a fertile ground for an evolution towards a 'welfare society' through growing development of the so-called 'third sector', that is, a social sector that exists on an intermediate between the state and the 'market'. Social sector includes a series of collective bodies with a private structure, pursuing realization of social functions, typically falling within the domain of welfare state.

This sector has been the subject of a recent legislative intervention in Italy ${ }^{2}$.

Essential characteristics of the third sector entities are: the private nature, the lack of pursuit of 'subjective' aim of profit and the presence of civic aims of solidarity and social utility, such as protection of environment, of developing countries.

In order to ensure the effective (subjective) non-profitability of Third Sector entities, there is a number of constraints on the management of the company: the assets must be used for performance of the statutory activity for the exclusive pursuit of civic, solidarity and social utility purposes and there is an express prohibition of distribution, even indirect, of profits (Art. 8 of the Third Sector Code); among the acts of indirect distribution are expressly listed typical management operations; in the event of extinction or dissolution of the entity, the remaining assets must be donated to other entities in the third sector (Art. 9 of the Third Sector Code); finally, the third sector entities are subject to a series of external controls and (when they exceed certain thresholds) they have to publish a social report: a document in which the body highlights its ability to be effective in the pursuit of the social mission (Art. 14 of the Third Sector Code).

From an organizational point of view, the Third Sector Code dictates a very articulated set of rules on the subject of constitution and bodies, which in many respects refers to the rules governing companies (capital or cooperative). The bodies of the third sector also include the so-called social enterprises that can be constituted in corporate form, provided that: (i) carry out an activity of general interest (ii) nonprofit-making (iii) for civic, solidarity and social utility purposes ${ }^{3}$.

The main peculiarity of these entities is the possibility of reimbursement the capital actually paid up to the shareholder, - provided for social enterprises constituted in corporate form only - and eventually revalued or increased within certain limits (Art. 3, Legislative Decree No. 112 of 3 July 2017).

This business model allows to significantly extend the application of the rules of the law of profit-making companies to bodies with altruistic aims.

The partial recognition of 'subjective profit' for those who participate in the social enterprise requires the interpreter to ask himself whether this model therefore imposes a duty on the administrative body, in addition to pursuing the altruistic aims to which

2 The so-called "Code of the Third Sector" which refers to the Italian Legislative Decree n. 117/2017.

3 The social enterprise is subject to a specific regulation, contained in Legislative Decree No. 112 of 3 July 2017. 
the social enterprise is primarily intended, also to exercise the activity of the enterprise in such a way as to maximize the possibilities of a concrete, effective recognition of this subjective profit. In the social enterprise model (unlike the benefit company, the focus of this paper's following paragraphs) the limitation to the purpose of profit would seem to affect the level of subjective profit without impacting the manner in which the business activity is carried out, requiring a lesser interference in the management of the business.

\section{Tools to promote a sustainable business model for profit-oriented enterprise}

The models examined so far refer, however, to the entities that, in principle (with the partial exception provided for social enterprises), fall into the category of non-profit entities.

The role of company law, on the other hand, would be more incisive if it were able to influence the strategies of large companies and business groups that carry out commercial activities.

A first step in this direction was taken in Italy, with the introduction - in implementation of the European Union Directive 2014/95/EU through Legislative Decree no. 254 of 30 December 2016 - of the obligation for large public interest entities to draw up and publish a non-financial declaration (individual or consolidated), which must contain information for each financial year about the aspects related to environmental, social, personnel, human rights and the fight against active and passive corruption. More specifically, the non-financial declaration contains at least information regarding: a) the use of energy resources, distinguishing between those produced from renewable and non-renewable sources, and the use of water resources; $b$ ) emissions of greenhouse gases and polluting emissions into the atmosphere; $c$ ) the impact, where possible on the basis of hypotheses or realistic scenarios even in the medium term, on the environment and on safety, associated with the risk factors or other relevant factors of environmental health risk (etc.).

At the hermeneutical level we have assisted to the affirmation of the so-called "theory of the corporate social responsibility", according to which the pursuit of the interests of subjects other than shareholders (including the environment, workers, consumers, etc.) must represent one of the objectives of the business (and therefore affect the duties of the directors). This theory, drawing its origins from the German theory of the Unternehmen an sich and evolving into the most recent American version of the Team Production Theory, has found its (timid) legislative recognition in the Italian legal system in Art. 103, paragraph 3-bis, of Legislative Decree 58/1998. This theory has some limits considering the indefinite contents and the very (overly) wide application perimeters, such as to include the protection of decidedly heterogeneous interests, unsuitable to act as guidelines for the conduct of the administrators and for its verification.

At present, therefore, in the Italian legal system still prevails the idea that the director of a capital company cannot grant a prerogative to the pursuit of the interests 
of third parties over those of the 'owners' of the company and must, on the contrary, strive primarily to achieve and protect the interests of the partners.

\section{The North American context}

In the North American context, the need to adopt company law rules aimed at bringing companies to act in a socially responsible manner has long been felt.

This need stems from a jurisprudence that for some time (referring to the well-known Dodge vs. Ford case of 1919) had affirmed the principle of 'shareholder supremacy'.

It is in this context that studies on Corporate Social Responsibility were developed also in North American culture, with the affirmation, among other things, of the aforementioned Team Production Theory, and the so-called constituency statutes began to be introduced (in the 1980s) in various North American countries, i.e., regulatory acts that legitimized (with no obligations) directors to advocate, in the exercise of their activities, not only the interests of shareholders but also those of stakeholders.

We assist then to the diffusion (firstly) of B-Corp certification and the introduction of a legal form that pursues a stable social purpose such as the benefit corporation.

Companies that demonstrate that they exceed certain external evaluation standards can acquire the status of Certified B-Corp ${ }^{\mathrm{TM}}$ and forge, therefore, with regard to the market, a recognition of the merits of their sustainable business model. Today, more than 2700 companies in 64 countries around the world have this status, including many countries in the European Union).

The second instrument - that of the benefit corporation - certainly has a greater role in the affirmation of values of social utility in the performance of business activities, giving a stable and lasting form to the objective of pursuing the interests of stakeholders in the governance of profit-oriented companies.

The benefits corporation for the first time has been introduced in the legislation of Maryland (2010), and has now spread across 34 North American States including Delaware. These are profit-oriented companies characterized by an express obligation on the part of the directors to also consider the interests of the stakeholders in the choices relating to the management of the company. These companies are required to publish the results of their pursuit of the common benefit purpose in a report and are subject to the private enforcement tool consisting in the remedy of the benefit enforcement proceeding, i.e. a social action - recognized in the first place by the company and in a derivative way by its shareholders - in the event of non-compliance with the obligation mentioned above.

\section{The benefit company in Italy}

The benefit company has also been introduced in Italy with the law 208/2015, inspired by the US one, but with its own specific rules.

Benefit companies are defined as companies that 
in the exercise of an economic activity, in addition to the purpose of sharing profits, pursue one or more goals of common benefit and operate in a responsible, sustainable and transparent way towards people, communities, territories and environment, cultural and social assets and activities, bodies and associations,

and, with a very extensive formula,

towards every subject involved in the benefit company: workers, customers, suppliers, lenders, creditors, public administration and civil society 4 .

Specific rules regarding management and market information are provided. Benefit companies must be managed in such a way as to balance: (i) shareholders' interests; (ii) the pursuit of common interest aim and (iii) the interests of the categories involved in the activity of the benefit company. The application of these rules represents a duty of the directors which, if violated, involves a breach of the obligations established by the law and the bylaws while making the directors subject to liability.

The benefit company must also annually draft a report regarding the pursuit of the common benefit.

A significant obligation is to indicate in the report the assessment of the impact of the business activity, carried out by an external auditor according to specific criteria established by law. With regard to the issues addressed in the current article, of particular interest is the obligation to assess the impact of business activity on the environment and thus on the life cycle of products and services, precisely in terms of the use of resources, energy, raw materials.

The words Società Benefit or the abbreviation "SB" in the name and in the documentation signals to the market and consumers that the business activity is also inspired by the purposes of common benefit and can be a key reason for the purchase choices.

\section{Management duties of the benefit company directors}

The most interesting profile regards the management duties of the benefit company directors. Are we dealing with an alternative model of company management compared to the purely profit-oriented one, or must the directors of a benefit company still pursue the purpose of profit for the shareholders, while balancing this goal with the realization of a common benefit, as indicated by the law?

The rules of the benefit company have already given rise to debate that discusses the ways through which lucrative goals, purposes of common benefit and the interests of the stakeholders can be pursued by the directors (and by the shareholders, where they have managerial powers by law or bylaws). It is discussed: (i) if the "altruistic contamination" concerns the object and the business activity exercise or the purpose of profit; (ii) what degree of specificity and seriousness must the purpose of common benefit pursued by the benefit company have; (iii) where the equilibrium point among the various objectives to be pursued is placed in terms of management.

4 See comm. 376 and 378 of the Law 208/2015. 
Certainly, benefit company rules represent a clear position in favour of a balanced sacrifice of the interest in maximizing the shareholders' profit in the name of the interests of the stakeholders and the aim of common benefit: it seems that the law drives the company directors to seek such balance in carrying out their duties.

The management of the company must be carried out "in such a way as to balance the interests of the shareholders, the pursuit of the objectives of common benefit and the interests of the categories" (Art. 1, par. $3801.208 / 2015$ ) that the law indicates and which are provided for in the bylaws. More generally, rules state that the purposes of common benefit "are pursued through a management aimed at balancing with the interest of the members and with the interest of those on whom the social activity can have an impact" (Art. 1, co. 377, L. 208/2015). Consistently, the non-observance of the obligation to manage the company in the manner established is expressly qualified as non-fulfilment of the duty of care and not in compliance with the law and the bylaws.

In the first comments it was emphasized how the plurality of purposes that can be pursued by the directors increases their level of flexibility in the adoption of management choices: and, consequently, the directors should be guaranteed by the unquestionability of these choices (business judgment rule), provided them to be in compliance with the law and the bylaws and with the duty of care due to a company director.

However, this opinion should take into account the fact that expanding management options, as intended by the legislator, must be understood in a sense that the choice limiting the maximization of profit cannot be questioned if justified, in a balanced way, by the pursuit of common benefit. The fact must also be noted that the pursuit of this purpose, specifically set down in the bylaws and characterizing the company's goal, cannot be neglected in the name of safeguarding the profit: the rules, when imposing balancing of the shareholders' interests with the pursuit of purposes regarding common benefit and stakeholders' interests, ought to limit the discretionary management in the sense that the balance cannot be resolved, in principle, by choosing to pursue only one set of the interests intended to be balanced.

This is confirmed by two specific rules.

The first is the rule that, in the context of the report on the pursuit of the common benefit, in addition to the description of the specific goals, procedures and actions implemented by the directors for the pursuit of the common benefit purpose, must also indicate the circumstances that have prevented or slowed down the execution of this purpose (Art. 1, co. 382, 1. 208/2015): therefore, the failure to pursue or even the simple slowing down of the pursuit of this purpose is qualified as a management deviation to be specifically accounted for.

The second rule concerns the specific sanction for failure to pursue the common benefit. It establishes the terms of consumer protection from the violation of this duty: it, therefore, affirms the non-compliance with the law and the bylaws of a management that does not pursue the common benefit and expressly exposes the directors to liability for damages, either for the sanction that was imposed, or for the loss of the company's reputation that may derive from it. Sanctions and responsibilities which can be augmented by those concerning unfair competition that could well be linked to the undue reputational advantage that derives from the quality of the benefit company in favour of a company that, despite its 'name', does not pursue the purposes of common benefit. 


\section{The preferable interpretation of duties pertaining to directors of a benefit company}

It is preferable to read the rules of the benefit company, seeking for a qualitative difference between the profit-oriented company and the benefit company in the ways in which the company operates. A qualitative difference that the benefit company's shareholder has chosen, deciding to buy benefit company' shares. And this difference can be grasped under two profiles.

The first profile stems from the observation that the impact of the exercise of a business activity on interests and needs other than those of profit has assumed increasing importance even in the regulation of 'pure' lucrative companies or of lucrative companies, such as companies with public shareholders, which must take into account, in their management, interests other than those of the shareholder. It is true that this relief does not affect the profit-making objectives that managers must pursue. It is also true, however, that the growing importance, even if only of the information to the market, of these profiles of the company's business has an impact on the behaviour of the lucrative companies' managers. Moreover, no one prohibits a lucrative company from pursuing purposes of common benefit. This choice - always on the reputational level - could well be coherent with lucrative goal. The result is a reading of the rules on the Benefit Company that places the pursuit of common benefit purposes on a qualitative level higher than the one pursued by a 'purely' lucrative company.

The second profile is drawn from the wording of Art. 1, co. 376, 1. 208/2015, where it is specified that the benefit companies not only pursue one or more purposes of common benefit but "operate in a responsible way towards people, communities, territories and environment, cultural and social goods and activities, bodies and associations and other stakeholders”.

The directors of a benefit company fulfil their duty of care in harmony with the law and the bylaw, not only pursuing the aim of common benefit specified in the bylaw, but also (and only) if, in the exercise of business activity, adopting general standards of behaviour that correspond to "responsibility, sustainability and transparency" and which, by definition, cannot be demonstrated as a mere respect of the law to which all are subject, but instead are to be implemented by aligning with the best practices of sustainable business activity.

This conclusion is once again confirmed in the content of the information that the benefit company must give to the market: the regulation of the benefit company includes the obligation to draw up a report regarding the pursuit of the common benefit.

\section{Conclusions}

The benefit company is an institute that establishes that the Italian legal system allows companies to pursue the profit together with common benefit purposes (where the words evokes the distinction from the egoistic benefit of the members). It marks an express stance favouring the possibility of proportional sacrifice of shareholders' 
interest in maximizing the profit in the name of balancing the interests of the stakeholders and those of common benefit: the obligations of benefit companies' directors seem likely to be drawn on the pursuit of such a balance.

Institutions like the benefit company are entrusted with the construction of the social market economy that should be the aim of the European corporate law.

\section{BIBLIOGRAPHY}

\section{Literature}

1. Angelici C. La società per azioni e gli "altri" (The joint-stock company and the "others"). In: L'interesse sociale tra valorizzazione del capitale e protezione degli stakeholders (The social interest between capital enhancement and stakeholder protection), Milano, 2010.

2. Angelici, Denozza, Marasà, M. Stella Richter Jr., Zoppini, Ventura. Dalla Benefit Corporation alla Società Benefit (From the Benefit Corporation to the Benefit Company). A cura di De Donno-Ventura, Cacucci editore, Bari, 2018.

3. Blair M. M., Stout L. A Team Production Theory of Corporate Law. Virginia L. Rev., No. 85, 1999,247 ss.

4. Blair M. M., Stout L. A. Director Accountability and the Mediating Role of the Corporate Board. Washington University Law Quarterly, Vol. 79, 2001. Available at: https://ssrn.com/ abstract=266622 [last viewed April 1, 2019].

5. Calandra Bonaura. Responsabilità sociale dell'impresa e doveri degli amministratori (Corporate social responsibility and directors' duties). In: Studi in ricordo di Pier Giusto Jaeger (Studies in memory of Pier Giusto Jaeger), Milano, Giuffré, 2011.

6. Cooney K., Koushyar J., Lee M., Murray H. Benefit Corporation and L3C adoption: A survey. Stanford Social Innovation Review, 2014.

7. Denozza-Stabilini. CSR and Corporate Law: The Case for Preferring Procedural Rules. Available at: https://ssrn.com/abstract=1117576 [last viewed April 1, 2019].

8. Marasà G. Imprese sociali, altri enti del terzo settore, società benefit (Social enterprises, other third sector entities, benefit companies). G. Giappichelli editore, 2019.

9. Prataviera, Società Benefit e responsabilità degli amministratori (Benefit company and directors' responsibility). Riv. soc., 2018.

10. Rescigno M. Impresa e comunità (brevi note a margine di recenti interventi normativi) (Business and community (short notes on the sidelines of recent regulatory changes)). Liber amicorum Pietro Rescigno, Editoriale Scientifica, Vol. II, 2018. 